\title{
Comparison of CE-Chirp and Click Auditory Brainstem Response Methods in Patients with Unilateral Total Hearing Loss
}

\author{
Tek Taraflı Total Işitme Kaybı Olan Hastalarda CE-Chirp ABR ve \\ Click ABR Yöntemlerinin Karşılaştırılması \\ (1) Seval Ceylan ${ }^{1}$, (1) Mustafa Şahin², (1) Mehmet Fatih Öğüt ${ }^{3}$ \\ ${ }^{1}$ Katip Çelebi University Atatürk Training and Research Hospital, Clinic of Otolaryngology, Audiology Unit, İzmir, Turkey \\ ${ }^{2}$ Aydın Adnan Menderes University Faculty of Medicine, Department of Otolaryngology, Aydın, Turkey \\ ${ }^{3}$ Ege University Faculty of Medicine, Department of Otolaryngology, İzmir, Turkey
}

Keywords

CE-Chirp ABR, Click ABR, unilateral, total hearing loss

Anahtar Kelimeler

CE-Chirp ABR, Click ABR, tek taraflı, total işitme kaybı

Received/Geliş Tarihi : 11.09 .2020

Accepted/Kabul Tarihi : 18.01.2021

doi:10.4274/meandros.galenos.2021.65487

Address for Correspondence/Yazışma Adresi: Mustafa Şahin Assoc. Prof.,

Aydın Adnan Menderes University Faculty of Medicine, Department of Otolaryngology,

Aydın, Turkey

Phone : +90 5336545502

E-mail : mustafa.kbb@gmail.com

ORCID ID: orcid.org/0000-0002-9009-6389

(C) Meandros Medical and Dental Journal, Published by Galenos Publishing House.

This is article distributed under the terms of the

Creative Commons Attribution NonCommercial 4.0

International Licence (CC BY-NC 4.0).

\begin{abstract}
Objective: To compare the V. wave latencies, amplitudes, and testing times of auditory brainstem response (ABR) using Click and CE-Chirp stimuli in patients with unilateral total hearing loss ( $\mathrm{HL})$.

Materials and Methods: Male patients with one normal ear and a total $\mathrm{HL}$ in the other were tested for Click and CE-Chirp ABR, Pure Tone Audiometry (PTA), Stenger, and Tympanometry. PTA thresholds in normal hearing ears were $20 \mathrm{~dB} \mathrm{HL}$ for each frequency, tympanogram resulted to type $A$, and Stenger was negative in total $\mathrm{HL}$. Click and CE-Chirp stimuli were sent using an alternating polarity and inserting ER 3A headphones (Rate: 20.1, High Pass Filter: $100 \mathrm{~Hz}$, and Low Pass Filter: 3,000 Hz). Ear with total HL tested with $100 \mathrm{~dB}$ and $95 \mathrm{dBnHL}$, normal hearing ear was tested with $80,60,40,30,20$, and $10 \mathrm{dBnHL}, 15 \mathrm{~dB}$, and $5 \mathrm{dBnHL}$ to determine the hearing level. ABR thresholds, V. wave latencies, amplitudes, and test times for each Click and CE-Chirp stimuli were compared.

Results: Results of 71 patients were analyzed. The CE-Chirp ABR wave $V$ amplitudes were higher at all levels except $80 \mathrm{dBnHL}$. Click ABR wave $V$ latencies at 80 and 60 $\mathrm{dBnHL}$ levels were longer $(p=0.00)$. CE-Chirp ABR wave $V$ latencies at $40 \mathrm{dBnHL}$ and below were longer $(p=0.00)$. CE-Chirp ABR thresholds $(12.81 \mathrm{dBnHL})$ were closer to $2-4 \mathrm{kHz}$ behavioral threshold averages $(10.45 \mathrm{dBnHL})$ than Click ABR thresholds (14.64 dBnHL). CE-Chirp ABR test time was shorter (14.57 \pm 3.83 vs. $17.91 \pm 3.94$ min, $\mathrm{p}=0.00)$.

Conclusion: The CE-Chirp stimulus was used to evaluate the normal hearing ear in patients with unilateral total $\mathrm{HL}$, which shortens the test time and provides closer results to behavioral thresholds. CE-Chirp ABR method is more advantageous than the Click ABR method to evaluate patients with unilateral total $\mathrm{HL}$.
\end{abstract}

Öz

Amaç: Tek taraflı total işitme kaybı olan hastalarda Click ve CE-Chirp uyaranları ile elde edilen işitsel beyin sapı yanıtı (ABR) eşiklerinin V. dalga latans ve amplitüdlerini ve test zamanlarını karşılaştırmaktır.

Gereç ve Yöntemler: Bir kulağı total işitme kayıplı, diğer kulağı normal işiten erkek hastalara Click ve CE-Chirp uyaranlar kullanılarak sedasyon altında ABR testi 
yapıldı. Pure Tone Odiyometri (PTA), Stenger testi ve Timpanometri testleri uygulandı. Normal işiten kulaklarında PTA eşikleri her frekans için $\leq 20 \mathrm{~dB} \mathrm{HL}$, timpanogram sonucu tip A ve total işitme kayıplı kulaklarında Stenger negatif olan kişiler dahil edildi. Click ve CE-Chirp uyaranlar alternating polarite ve insert ER 3A kulaklıklar ile gönderildi. Rate: 20,1, Yüksek Geçiren Filtre (HPF): $100 \mathrm{~Hz}$, Alçak Geçiren Filtre (LPF): $3.000 \mathrm{~Hz}$ olarak ayarlandı. Total işitme kayıplı kulaklar Click ve CE-Chirp uyaran kullanılarak $100 \mathrm{~dB}$ ve 95 $d B$ ses şiddetlerinde $A B R$ testi uygulandı. Normal işiten kulaklara 80,60,40,30,20, $10 \mathrm{~dB}$ ve eşik belirlemek için gerektiğinde $15 \mathrm{~dB}$, $5 \mathrm{~dB}$ düzeyinde sesler gönderildi. Click ve CE-Chirp uyaran ile gerçekleştirilen ABR eşikleri, dalga $V$ latansları, dalga $V$ amplitüdleri ve test süreleri karşıış̧ııııldı.

Bulgular: Yetmiş bir hastanın sonuçları incelendi. $80 \mathrm{~dB} n \mathrm{nHL}$ dışındaki bütün düzeylerde CE-Chirp ABR dalga $V$ amplitüdleri Click ABR dalga amplitüdlerinden daha büyüktü. 80 ve $60 \mathrm{~dB} \mathrm{nHL}$ düzeylerinde Click $A B R$ dalga V latansları CE-Chirp ABR dalga latanslarından uzun bulunurken $(p=0,00), 40 \mathrm{~dB} n \mathrm{~nL}$ ve altındaki düzeylerde CE-Chirp $A B R$ dalga $V$ latansları Click $A B R$ daha uzundu $(p=0,00)$. CEChirp ABR eşikleri (12,81 dB nHL) Click ABR eşiklerine (14,64 dB nHL) göre 2-4 KHz davranışsal eşik ortalamalarına (10,45 dB $\mathrm{nHL})$ daha yakındı. CE-Chirp ABR test süresi Click $A B R$ test süresinden daha kısaydı $(14,57 \pm 3,83$ vs. $17,91 \pm 3,94$ dakika, $p=0,00)$.

Sonuç: Unilateral total işitme kaybında CE-Chirp uyaran kullanımının ABR test süresini kısalttığı ve normal işiten kulaklarda davranışsal işitme eşiklerine daha yakın cevaplar sağladığı gözlenmiştir. Unilateral total işitme kayıplı hastaların değerlendirilmesinde CE-Chirp ABR yöntemi Click ABR yönteminden daha avantajlıdır.

\section{Introduction}

Brainstem auditory-evoked potentials (AEPs) are bioelectrical potentials that arise from specific neural activities in the auditory pathway from the cochlea to the auditory cortex after the presentation of an auditory stimulus (1). Although this electrical activity takes approximately 0.5 seconds with low severity, it can be recorded in case of voltage fluctuations using electrodes placed on the skin surface $(1,2)$. Auditory brainstem response ( $A B R$ ) is defined as AEPs that occurs in the process between 2-12 msec after auditory stimulation in healthy individuals (2). ABR results are recorded based on Click, tonal and Chirp techniques. In the Click ABR method, the sound wave reaches its peak from the basal region of the cochlea in a longer time. The low frequency region of the originated response emerges msec after the high-frequency region (3). Basal cells are not stimulated ubiquitously. Thus, nerve cells cannot occur simultaneously by depolarization. This situation is clarified as cochlear travel delay or cochlear delay (waves of sound circulation time in the cochlea) $(3,4)$. Chirp record is a newly defined stimulus for ABR evaluation (5). Chirp stimulus can be broad band Click-stimulus derivative CE-Chirp or narrow as frequency-specific tone-band derivative narrow-band CE (NB-CE) Chirp. In recent years, there is also a newly developed level specific (LS) Chirp stimulus (6). Frequency spectrums of Click and CE-Chirp stimuli are the same. CE-Chirp is a stimulus developed to assess ABRs. This stimulus can provide synchronous stimulation in the cochlea $(5,6)$. The difference of the CE-Chirp stimulus from the Click stimulus is the occurrence of delivery of low, medium and high-frequency components to stimulate all frequency regions in the cochlea simultaneously basal cells can achieve different frequency targets using CE-Chirp stimulus (7). Larger amplitude ABR waves are obtained by simultaneous depolarization in all frequency regions of the cochlea by CE-Chirp stimulus $(1,2)$.

This study was designed to compare the ABR test results obtained with CE-Chirp and Click stimuli in patients with unilateral total hearing loss.

\section{Materials and Methods}

This study was a cross-sectional analytical research. Ethical approval was obtained with the decision of Gülhane Military Medical Academy Ethics Committee (decision no: 50687469-1491-13914/1648.4-407, date: 25.02 .2014 ) for this study. This study was conducted in accordance with the Helsinki Declaration. Seventy-one men (18-25 years old) with one ear with total hearing loss and the other ear with normal hearing participated in the study. All individuals participating in the study were informed by experts and their verbal and written consents were obtained. According to the results of Pure Tone Audiometry (PTA), Stenger test and tympanometry tests, male patients with total hearing loss in one ear and hearing the other ear normally were included in the study. Among these patients, patients between the ages of 19-25 and PTA thresholds for normal hearing ears with $\leq 20 \mathrm{~dB} H \mathrm{HL}$ for each frequency were included in the study. Patients who were diagnosed with mental retardation, having psychiatric disease, and getting out of sleep were excluded from this study. 
In order for the patients to be included in the study, their normal hearing ears; for each frequency $20 \mathrm{~dB}$ HL PTA thresholds, type A tympanogram, negative Stenger test result were required. TABR thresholds, wave $\mathrm{V}$ latencies and wave $\mathrm{V}$ amplitude data were analyzed in patients' normal hearing ears. The time taken to obtain ABR responses via CE-Chirp and Click stimulus were also compared.

PTA tests were performed using the Interacoustics model AC40 (calibrated as per ANSI S3.6, 1996) (Interacoustics AS, Assens, Denmark) as the Pure Tone Audiometer device in the soundproof cabinet. PTA Airway thresholds (between $250-8,000 \mathrm{~Hz}$ ), bone path thresholds (between $500-4,000 \mathrm{~Hz}$ ) were tested. Headphones TDH 39 (Telephonics Co. Farmingdale, NY, USA) were used for airway transmission and vibrator RadioEar B-71 (RadioEar Co. Middelfart, Denmark) were used for bone conduction. Then, these patients underwent sedation and $A B R$ tests were performed with Click stimulus and CE-Chirp stimulus. The sedation of the patients was provided by the relevant anesthesia team. CMS- 60 model pulse oximeter device was used to control the pulse and oxygenation of the patient after sedation. In order to provide oxygen to the patient, 10 liters, 150 Bar, 1.5 $\mathrm{m}^{3}$ medical oxygen cylinder was kept in the room.

Click $A B R$ and CE-Chirp ABR tests were applied under the sedation to patients who conformed circumstances stated above. Interacoustic Eclips Ep 15 ABR system (Interacoustics, Middelfart, Denmark) was used for ABR testing and recording. The stimuli were calibrated to ISO 389-6 (2007) for the Click and to manufacturer's data for the Chirps. In ABR test protocol, electrodes with the positive line were placed on the upper forehead area, electrodes with the neutralized line were placed on the bottom side of the forehead, while one negative electrode was settled on to the mastoid process area on the left and other one was settled on to the mastiod process area on the right. The positive (active) electro was placed in the midline upper part $(\mathrm{Fz})$ of the forehead, the ground electrode in the midline (Fpz) of the forehead, the reference electrodes were placed in the right (M2) and left (M1) mastoid areas. Reference electrodes were placed on the right (M2) and left (MI) mastoid areas. Care was taken to ensure that the electrode-skin impedances are below $3 \mathrm{k} \Omega$ and that the cables do not overlap. Click and CE-Chirp stimuli were sent via the insert ER-3A (Etymotic Research) headphones with alternating polarity, rate: 20.1 . High Pass Filter: $100 \mathrm{~Hz}$, Low Pass Filter (LPF): 3,000 $\mathrm{Hz}$ and artefact exclusion level were set to $40 \mathrm{nV}$ in the measurements. The tests were started by sending monaural Click stimulus to the ears with total hearing loss. Ears with total hearing loss were tested at $100 \mathrm{~dB}$ and $95 \mathrm{~dB}$. While testing ears with total hearing loss, a mask sound was sent to normal hearing ears. Normal hearing ears of the patients were tested at levels such as $80,60,40,30,20,10 \mathrm{~dB}$ and, if necessary, $15 \mathrm{~dB}, 5$ $\mathrm{dB}$ to determine the threshold. After performing $A B R$ test using Click stimulus, ABR was performed using CE-Chirp stimulus with the same test technique. ABR wave $\mathrm{V}$ amplitudes (peak to following trough) and their latencies were determined.

The preparation stage of the patients for the test was not included in the test period. When the patients were asleep for the test, the tests were started and the test times were recorded.

\section{Statistical Analysis}

Statistical analysis was performed using SPSS 20.0 program (IBM SPSS Statistics for Windows, Version 27.0. Armonk, NY: IBM Corp, USA). Click ABR and CEChirp ABR for dependent variables in comparing the differences between wave latency findings; Paired t-test) between the means of paired data averages was chosen as the method. Kolmogorov-Smirnov test was used to test normality assumption. Click ABR and CE-Chirp ABR test time comparison (Paired t-test) method was used. ANOVA "One-Way Analysis of Variance" was used to control the proximity between the Click ABR threshold, the CE-Chirp ABR threshold and the PTA 2-4 KHz thresholds, and the average of the 2-4 KHz threshold, and the Tukey test was used to control the factor that caused the difference. Tukey test was applied to control the factor that caused all the difference with a significance level of $95 \%$ or $\alpha=0.05$.

\section{Results}

In this study, the data obtained from 71 male patients between the ages of 19-25 who had a mean age of 28.6 were evaluated. Twenty-eight of the patients had right (39.4\%) and 43 (60.6\%) of the patients left ears had total hearing loss. ABR waves were not observed with both types of stimuli in ears with total hearing loss. Pure sound tonal 
audiometry thresholds of normal hearing ears are shown in Table 1. The differences of the thresholds were examined using One-Way ANOVA [Tukey t-test (phostoc)] method in the normal hearing ears. As a result, PTA was determined as $2-4 \mathrm{KHz}$ threshold average $<$ CE-Chirp ABR threshold < Click threshold. According to the CE-Chirp ABR thresholds, PTA was found closer to the $2-4 \mathrm{KHz}$ threshold averages compared to the Click ABR thresholds (Figure 1). One-Way ANOVA (Tukey t-test method) was used to examine the differences of the thresholds in the normal hearing ears of the patients. Click ABR thresholds was

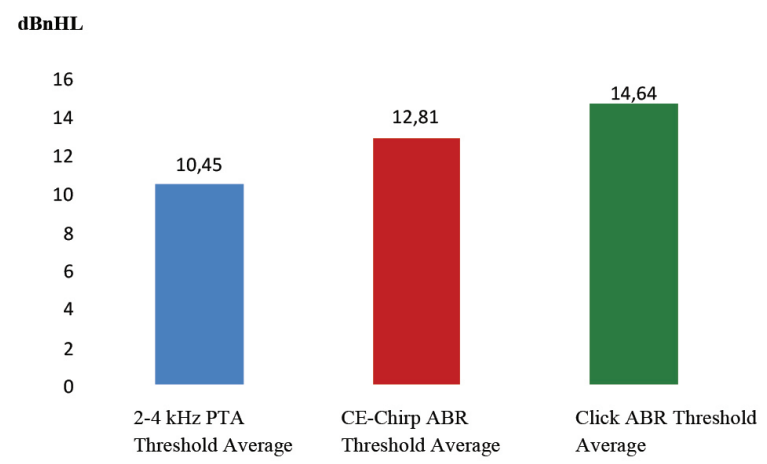

Figure 1. Comparison of Click ABR and CE-Chirp ABR avarage thresholds in terms of proximity to the $2-4 \mathrm{KHz}$ pure tone audiometry avarage threshold in normal hearing ears of patients

ABR: Auditory brainstem response, PTA: Pure Tone Audiometry seen to be different from the behavioral thresholds than the PTA thresholds. Results closer to the $4 \mathrm{KHz}$ thresholds were found compared to the $2 \mathrm{KHz}$ and 2-4 $\mathrm{KHz}$ threshold averages (Figure 2). It was also investigated to which frequency region the CE-Chirp $A B R$ thresholds were closer than the behavioral thresholds. Thus, CE-Chirp ABR Threshold PTA was found similar and close to the $4 \mathrm{KHz}$ threshold. CEChirp ABR thresholds were found close to the 2-4 $\mathrm{KHz}$ threshold average after $4 \mathrm{KHz}$ and the latest 2 $\mathrm{KHz}$ PTA thresholds. We should note that CE-Chirp $A B R$ thresholds are very close to similar to behavioral thresholds to $4 \mathrm{KHz}$ thresholds (Figure 3, Table 2). According to the results obtained by comparison

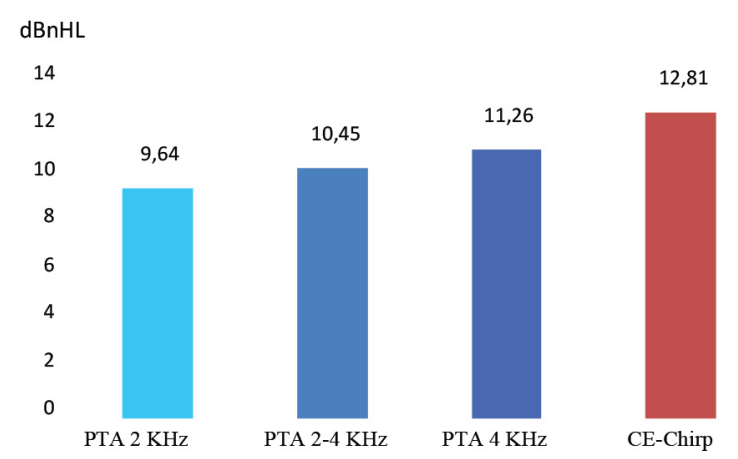

Figure 2. Click ABR thresholds and PTA thresholds of patients' normally hearing ears

ABR: Auditory brainstem response, PTA: Pure Tone Audiometry

\begin{tabular}{|c|c|c|c|c|c|c|c|}
\hline & & $250 \mathrm{~Hz}$ & $500 \mathrm{~Hz}$ & $1,000 \mathrm{~Hz}$ & $2,000 \mathrm{~Hz}$ & $4,000 \mathrm{~Hz}$ & $8,000 \mathrm{~Hz}$ \\
\hline \multirow[b]{2}{*}{ Right } & Air path $(\mathrm{dB})$ & 14.3 & 12.3 & 10.9 & 8.7 & 11.4 & 13.5 \\
\hline & Bone path $(\mathrm{dB})$ & 7.8 & 7.4 & 6.3 & 6.3 & 7.1 & 6.4 \\
\hline \multirow[b]{2}{*}{ Left } & Air path $(\mathrm{dB})$ & 17 & 14.5 & 13.2 & 10.5 & 11.6 & 13.9 \\
\hline & Bone path $(\mathrm{dB})$ & 11.3 & 9.5 & 8.2 & 8.4 & 7.9 & 7.9 \\
\hline
\end{tabular}

Table 2. The relationship between CE-Chirp ABR thresholds and behavior thresholds of patients' normal hearing ears

\begin{tabular}{|l|l|l|l|}
\hline Test & Number of patients & $\mathbf{1}$ & $\mathbf{2}$ \\
\hline Pure Tone Audiometry 2 KHz threshold average & 71 & $9,6479 \mathrm{~dB} \mathrm{nHL}$ & - \\
\hline Pure Tone Audiometry 2-4 KHz threshold average & 71 & $10,4577 \mathrm{~dB} \mathrm{nHL}$ & - \\
\hline Pure Tone Audiometry 4 KHz threshold average & 71 & $11,2676 \mathrm{~dB} \mathrm{nHL}$ & $11,2676 \mathrm{~dB} n \mathrm{HL}$ \\
\hline CE-Chirp ABR threshold & 71 & & $12,8169 \mathrm{~dB} \mathrm{nHL}$ \\
\hline & - & 0.125 & 0.153 \\
\hline ABR: Auditory brainstem response & & & \\
\hline
\end{tabular}


statistical tests, wave $V$ latencies were found to be longer at $80 \mathrm{~dB} \mathrm{nHL}$ and $60 \mathrm{~dB} \mathrm{nHL}$ than CE-Chirp ABR method with Click $A B R$ method $(p=0.00)$. Contrary to high intensities at $40 \mathrm{~dB} \mathrm{nHL}, \mathrm{CE}$-Chirp wave $\mathrm{V}$ latencies were shorter than Click $A B R$ wave $V$ latencies $(p=0.00)$ (Figure 4). At $80 \mathrm{~dB} n \mathrm{HL}$, Click $A B R$ wave $V$ amplitudes were larger than CE-Chirp ABR wave $V$ amplitudes, while at lower levels CE-Chirp ABR wave $V$ amplitudes were recorded as larger than Click $A B R$ wave $V$ amplitudes (Figure 5). The CE-Chirp ABR test time was found to be shorter than the Click $A B R$ test time [(14.57 \pm 3.83 vs. $17.91 \pm 3.94)$ minutes, $p=0.00]$. The preparation stage of the patients for testing was not included in the test time. The test was started when the patients went to sleep required for the test, and from this moment on, the test times were recorded.

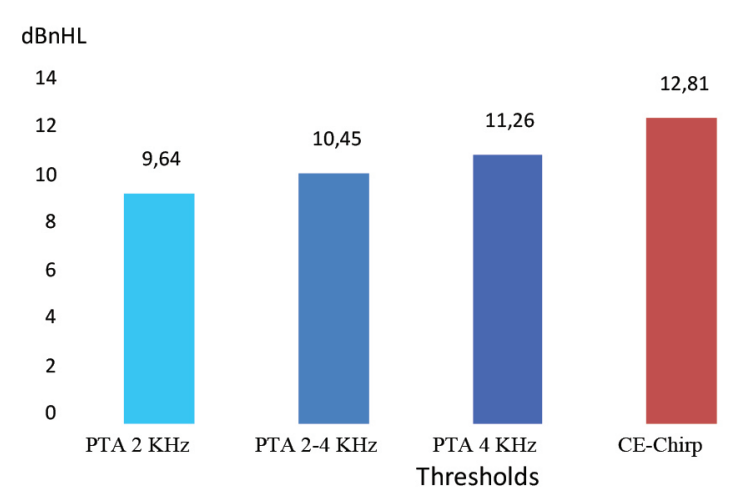

Figure 3. CE-Chirp ABR thresholds and PTA thresholds of patients' normally hearing ears

ABR: Auditory brainstem response, PTA: Pure Tone aAudiometry

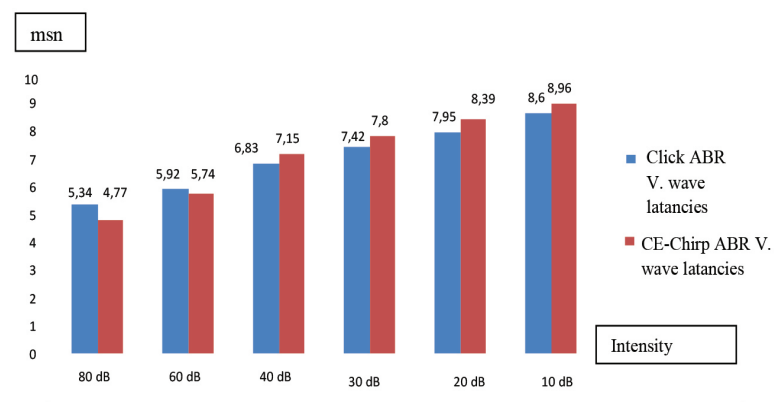

$(P=0.00) \quad(p=0.00) \quad(p=0.00) \quad(p=0.00) \quad(p=0.00) \quad(p=0.00)$

Figure 4. Comparison of Click $A B R$ and CE-Chirp ABR wave $V$ latencies of normal hearing ears of patients

ABR: Auditory brainstem response, PTA: Pure Tone Audiometry

\section{Discussion}

In our study, ABR waves were not observed with both types of stimuli for the ears of patients in total hearing loss. In patients' normal hearing ears, CEChirp ABR thresholds (12.81 dB $\mathrm{nHL}$ ) were found closer to the average of $2-4 \mathrm{KHz}$ behavioral thresholds (10.45 dB nHL) than the Click ABR thresholds (14.64 dB $\mathrm{nHL}$ ) (Figure 1). Example Click $A B R$ and CE-Chirp $A B R$ images demonstrate that the CE-Chirp ABR threshold is determined $5 \mathrm{~dB}$ lower than the Click $A B R$ threshold. Prigge et al. (6) reported that individuals with normal hearing had more reliable feedbacks than CE-Chirp stimulus and Click stimulus, and CE-Chirp stimulus was the ideal stimulus regarding threshold estimation. In our study, the closeness of CE-Chirp ABR thresholds and Click $A B R$ thresholds to behavioral threshold averages of $2 \mathrm{KHz}, 4 \mathrm{kHz}, 2-4 \mathrm{kHz}$ were also examined. It is noteworthy that CE-Chirp ABR thresholds are very close to similarly to behavioral thresholds to $4 \mathrm{kHz}$ thresholds.

In 30-35 dB nHL, result of "passed" in hearing screening was obtained with CE-Chirp ABR more than CE-Chirp stimulus results by comparison of 40 newborns with a risk of hearing loss and no risk of hearing loss based on Almeida et al. (8) findings. In their study, Cebulla et al. (9) investigated the waveform morphology, latency, and amplitude values in newborns and compare them with those evoked by the Click. Their findings showed that regardless of the type of stimulus in 96 newborns at $60 \mathrm{~dB} \mathrm{nHL}$, wave $V$ was present in all newborns, at $40 \mathrm{~dB} \mathrm{nHL}$; wave $\mathrm{V}$. was present as $95 \%$ with Click ABR, while Chirp ABR was determined as $100 \%$ (9). Khorsand et al. (10)

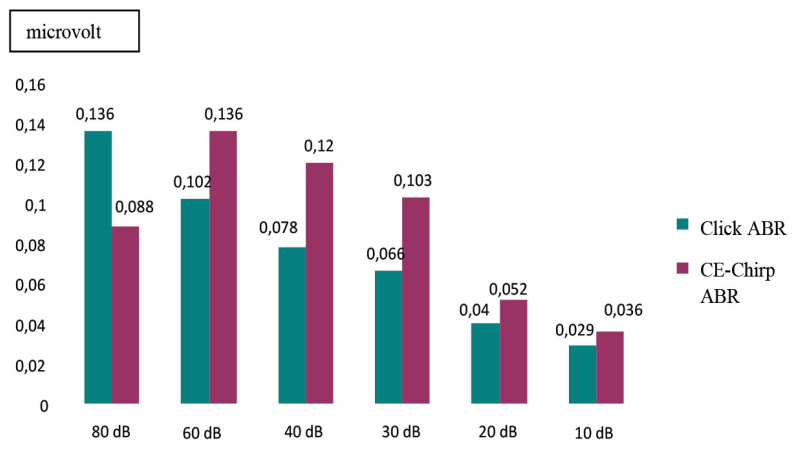

Figure 5. Comparison of Click $A B R$ and CE-Chirp ABR wave $V$ amplitude sizes of the patients' normal hearing ears

ABR: Auditory brainstem response 
studied on the CE-Chirp and Click ABR comparison and they repoerted that thresholds of $\mathrm{V}$. wave in 15 individuals with no hearing impairment between the ages of 20-30 and CE-Chirp ABR wave $V$ thresholds were obtained approximately $5 \mathrm{~dB}$ better than the Click ABR wave $V$ thresholds (10).

In our study, CE-Chirp ABR wave $V$ amplitudes were found to be larger in all ears except normal $80 \mathrm{~dB} \mathrm{nHL}$ than Click $A B R$ wave $V$ amplitudes demonstrated in Figure 5. Consistent with our findings, Khorsand Sabet et al.'s research showed that in 15 individuals with normal hearing had bigger amplitudes than Click $A B R$ wave $V$ amplitudes than CE-Chirp $A B R$ at $20,40,60 \mathrm{~dB}$ sound intensity. Click $A B R$ wave $V$ had bigger amplitudes than than that of CE-Chirp ABR at $80 \mathrm{~dB}$ nHL (10). Similarly, a study was conducted by Rodrigues and Lewis (5) conducted with 12 adults with normal hearing, their findings showed that higher levels of amplitude than CE-Chirp ABR and Click ABR were obtained in all levels $(60,40,30,20,10 \mathrm{~dB} \mathrm{nHL})$ except $80 \mathrm{~dB} \mathrm{nHL}$.

Compatible with our findings, in their study, Stuart and Cobb (11). In their study in which they compared the results of $A B R$ tests with CE-Chirp and Click stimuli in 23 newborns at $30 \mathrm{~dB} \mathrm{nHL}$, their findings showed that larger wave $\mathrm{V}$ amplitudes were obtained with CE-Chirp stimulus. There are some other studies indicating that the deficiency in normal hearing ears at $80 \mathrm{~dB} \mathrm{nHL}$ with CE-Chirp stimulus to provide lower amplitude responses than Click stimulus and can be eliminated by LS Chirp stimulus. Elberling et al. (12) studied to compare ABR test results obtained via LS Chirp, classical CE-Chirp and Click stimulus in normal hearing individuals. They reported bigger amplitudes in LS Chirp stimulus than both CE-Chirp ABR and Click $\mathrm{ABR}$ at $80 \mathrm{~dB} \mathrm{nHL}(12)$.

Cargnelutti et al. (13) obtained larger wave $\mathrm{V}$ amplitudes compared to LS stimulus and Click stimulus by performing a comparative study with LS CE-Chirp ABR and Click ABR results at $85 \mathrm{~dB} \mathrm{nHL}$ in 30 individuals with normal hearing. Since our research was conducted using sedation when the patient went to rest required for the test, the tests were started and the test times were recorded from this moment. In this respect, both ABR methods were applied equally and simultaneously in our study, which makes our research advantageous regarding comparing $A B R$ test times performed with both stimulus types. In our study, CE-Chirp ABR test time was shorter than Click $A B R$ test time $[(14.57 \pm 3.83$ vs. $17.91 \pm 3.94)$ minutes, $\mathrm{p}=0.00]$.

Inconsistent with our findings, Almeida et al.'s (8) findings showed application time of CE-Chirp ABR test at 30-35 dB nHL was shorter than that of Click $A B R$ test and results' potentials were compared with Click stimulus and Chirp stimulus in 96 newborns (8). Greater amplitude responses were obtained with Chirp ABR, and more reliable test results besides shorter test time were reported (9). It has been shown to be five minutes faster (14).

In a study on the use of CE-Chirp stimulus for monitoring during surgery which was conducted by Di Scipio and Mastronardi (15). Their findings showed that the use of Chirp ABR during surgery provides a rapid response with larger wave amplitudes and may also provide faster feedback to the surgeon who performs the surgery (15).

There are also studies showing that the Chirp stimulus has areas of use other than the ABR test. Chertoff et al. (16) achieved larger N1 wave amplitudes in the Combined Action Potentials performed with Chirp stimuli in 16 adults with normal patients.

NB-CE Chirp ASSR thresholds and Tone Burst ABR thresholds for closeness to behavioral thresholds in children with normal and hearing loss patients were compared in Venail et al.'s (17) studies. It has been reported that there is a high degree of correlation between NB-CE Chirp ASSR thresholds and 0.5, 1, 2, 4 $\mathrm{KHz}$ behavioral thresholds (18). These results suggest that the clinical use of Chirp stimulus may also become widespread in other electrophysiological audiology test applications.

\section{Conclusion}

CE-Chirp ABR thresholds were found closer to PTA thresholds than Click ABR thresholds in normal hearing ears of patients with unilateral total hearing loss. It has also been found that ABR can be performed in a shorter time with the CE-Chirp stimulus.

The findings obtained in this study suggest that the use of CE-Chirp stimulus in patients with unilateral total hearing loss shortened the time of $A B R$ testing and provided closer responses to behavioral thresholds (PTA thresholds) than Click ABR thresholds in normal hearing ears of patients with unilateral total hearing loss. The results of this study; supports that 
the use of CE-Chirp stimulus may be more appropriate compared to Click stimulus when performing ABR test in patients with unilateral total hearing loss.

\section{Ethics}

Ethics Committee Approval: Ethical approval was obtained with the decision of Gülhane Military Medical Academy Ethics Committee (decision no: 506874691491-139-14/1648.4-407, date: 25.02.2014) for this study.

Informed Consent: All individuals participating in the study were informed by experts and their verbal and written consents were obtained.

Peer-review: Externally peer-reviewed.

\section{Authorship Contributions}

Concept: S.C., M.F.Ö., Design: S.C., M.Ş., M.F.Ö., Supervision: M.F.Ö., M.Ş., Fundings: S.C., M.F.Ö., Materials: S.C., M.Ş., Data Collection or Processing: M.Ş., S.C., M.F.Ö., Analysis or Interpretation: S.C., M.Ş., M.F.Ö., Literature Search: M.Ş., S.C., M.F.Ö., Writing: S.C., M.Ş., Critical Review: M.Ş., M.F.Ö., S.C.

Conflict of Interest: No conflict of interest was declared by the authors.

Financial Disclosure: The authors declared that this study received no financial support.

\section{References}

1. Hall JW. Overview of auditory neurophysiology; Past, present and future. New handbook of Auditory Evoked Responses.1st ed. Boston: Pearson Education; 2007: p.34.

2. Burkard R, McNerney K. Introduction to Auditory Evoked Potentials. In: Katz J, Burkard R, Medwetsky L, Hood L. Handbook of Clinical Audiology. 6th ed. USA: Williams and Wilkins; 2009: p.222-41.

3. Dau T, Wegner O, Mellert V, Kollmeier B. Auditory brainstem responses with optimized chirp signals compensating basilarmembrane dispersion. J Acoust Soc Am 2000; 107: 1530-40.

4. Shore SE, Nuttall AL. High-synchrony cochlear compound action potentials evoked by rising frequency-swept tone bursts. J Acoust Soc Am 1985; 78: 1286-95.

5. Rodrigues GRL, Lewis DR. Comparison of Click and CE-Chirp stimuli on Brainstem Auditory Evoked Potential recording. Rev Soc Bras Fonoaudiol 2012; 17: 412-6.
6. Prigge L, Weller S, Weather by L. Auditory Brainstem Response and The Travelling Wave Delay. Canadan Hearing Report October 2012; 7: 33-4.

7. Elberling C, Don M. Auditory brainstem responses to a chirp stimulus designed from derived-band latencies in normalhearing subjects. J Acoust Soc Am 2008;124:3022-37.

8. Almeida MG, Sena-Yoshinaga TA, Cortes-Andrea IF, Sousa MNC, Lewis RL. Automated auditory brainstem responses with CEChirp at different intensity levels. Audiol Commun Res 2014; 19: 117-23.

9. Cebulla M, Lurz H, Shehata-Dieler W. Evaluation of waveform, latency and amplitude values of chirp $A B R$ in newborns. Int J Pediatr Otorhinolaryngol 2014; 78: 631-6.

10. Khorsand Sabet V, Mandavi-Zafarghandi ME, Safavi M, Sharifian M, Tabatabaee SM. Comparison of click and CE-Chirp-evoked human auditory brainstem responses: a preliminary study. Aud 2014; 23: 69-76.

11. Stuart A, Cobb KM. Effect of stimulus and number of sweeps on the neonate auditory brainstem response. Ear Hear 2014; 35 : 585-8.

12. Elberling C, Kristensen SG, Don M. Auditory brainstem responses to chirps delivered by different insert earphones. J Acoust Soc Am 2012; 131: 2091-100.

13. Cargnelutti M, Cóser PL, Biaggio EPV. LS CE-Chirp ${ }^{\circledR}$ vs. Click in the neuroaudiological diagnosis by ABR. Braz J Otorhinolaryngol 2017; 83: 313-7.

14. Megha KN, Divyashree KN, Lakshmi A, Adithya S, Keerthana KP, Pushpalatha ZV, et al. Narrow-band chirp and tone burst auditory brainstem response as an early indicator of synaptopathy in industrial workers exposed to occupational noise. Intractable Rare Dis Res 2019; 8: 179-86.

15. Di Scipio E, Mastronardi L. CE-Chirp ${ }^{\circledR}$ ABR in cerebellopontine angle surgery neuromonitoring: technical assessment in four cases. Neurosurg Rev 2015; 38: 381-4.

16. Chertoff $M$, Lichtenhan J, Willis M. Click- and chirp-evoked human compound action potentials. J Acoust Soc Am 2010; 127 : 2992-6.

17. Venail F, Artaud JP, Blanchet C, Uziel A, Mondain M. Refining the audiological assessment in children using narrow-band CEChirp-evoked auditory steady state responses. Int J Audiol 2015; 54: 106-13.

18. Kristensen SG, Elberling C. Auditory brainstem responses to level-specific chirps in normal-hearing adults. J Am Acad Audiol 2012; 23: 712-21. 